\title{
Резонатор лазера \\ с интерференционно-поляризационным фильтром на основе фазовых интерферометров
}

\author{
А.А. Ковалёв \\ Институт физики полупроводников им. А.В. Ржанова СО РАН \\ *E-mail: kovalev@isp.nsc.ru
}

DOI:10.31868/RFL2018.118

Цель работы заключается в проектировании селектирующих устройств с низкими оптическими потерями, которые могут быть реализованы для многих типов лазеров при помощи стандартной технологии. В основу действия устройств положена фазовая характеристика интерферометра при коэффициенте отражения дальней грани, близком к единице [1].

В случае наклонного падения линейно поляризованная волна остается линейно поляризованной в точках «резонансов», где скорость расфазировки с изменением длины волны для $p$ - и $s$ - компонент может быть сделана высокой. Наклонный отражательный интерферометр выполняет роль фазосдвигающего элемента в лазерном фильтре Лио. Роль частичного поляризатора выполняет отдельная брюстеровская пластина. Рассчитаны резонаторы с одно- и двухэлементными фильтрами.

Рассчитаны параметры отражательного интерферометра с малой базой на основе тонкослойных покрытий для «грубой» селекции в лазере на красителях. Покрытия на основе сернистого цинка и криолита были выполнены методом

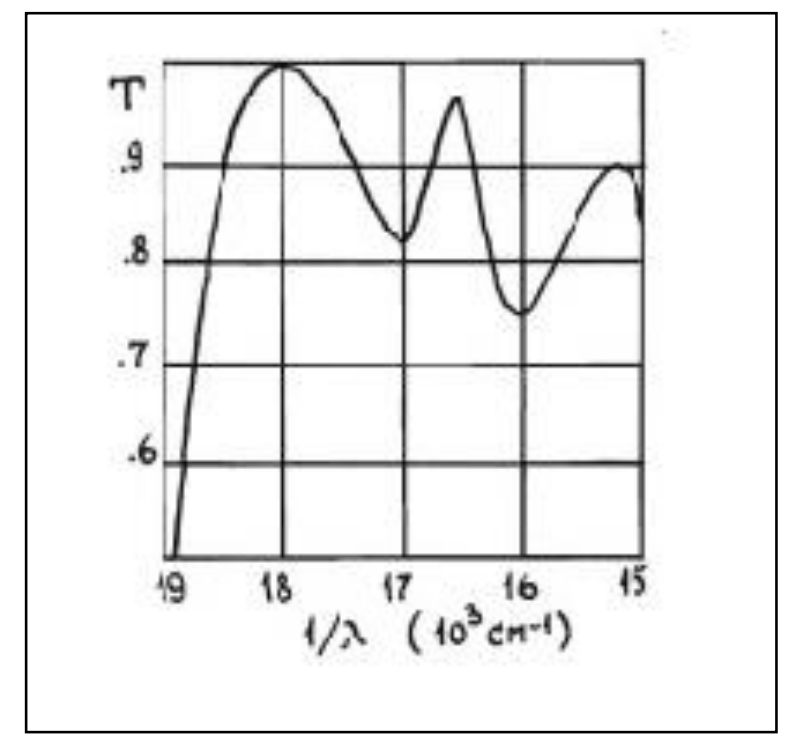

термического испарения в вакууме.

На рисунке приведена запись спектральной характеристики отражательного интерферометра. По ходу луча перед отражательным интерферометром и после него помещены поляризаторы, оси которых наклонены под $45^{\circ}$ к $p$ плоскости отражательного интерферометра. Имеетя согласие с расчетом. Ограничение на ширину рабочего максимума накладывают потери плотного зеркального покрытия $(\mathrm{R}=0.997)$.

\section{Литература}

[1] Троицкий Б.В. Квантовая электроника, 2, 2444 (1975) 